\title{
THE IMPLEMENTATION OF PEN-PAL PROJECT TO TEACH WRITING SKILL OF RECOUNT TEXT AT THE EIGHT CLASS OF SMP NASRANI 1 MEDAN
}

\author{
oleh \\ Daniel Fransihar Sibagariang ${ }^{1}$ (danielsibagariang1996@gmail.com) \\ Eka Lestari Sitompul² (ekalestarisitompul14@gmail.com) \\ Ana Maria Togatorop ${ }^{3}$ (togatoropannamaria@gmail.com) \\ Isni Salamah Tarigan ${ }^{4}$ (carolineisni73@gmail.com) \\ Irma Khoirot Daulay ${ }^{5}$ (irmakhoirotdaulay@unprimdn.ac.id)
}

\begin{abstract}
The purpose of this study to determine the implementation of the pen pal project in teaching recount text writing skills to eighth grade students. Moreover, this study also intends to determine students' responses to the learning strategy after the implementation of correspondence with their pen pals. This research used descriptive qualitative. The subject of this study was eighth grade students of SMP Nasrani 1 Medan. This study used an observation sheet to observe the implementation of a letter with pen pals in the learning and teaching process, for more accurate data, researchers distributed questionnaire sheets to students to find out the responses of students and conducted interviews with teachers of English studies on the implementation of the pen pal project. The results of this study indicate that exchanging letters with pen pals can trigger students' enthusiasm and desire to learn to write, especially writing recount texts. The results of this study also show that students can communicate effectively in English to express their ideas and thoughts about certain topics they like in their letters based on experiences they have experienced in the past. The students approved that using the pen pal project could help them to improve their writing abilities.
\end{abstract}

Key Words: Writing Skill, Pen Pals, Exchanging letter.

\section{A. INTRODUCTION}

Writing is the language skills needed to improve the quality of learning. Their mastery of writing skills, is expected to express their ideas, thoughts, and feelings that each student after undergoing a learning process in different types of writing, both fiction and nonfiction.

According Rosidi (2009: 3) writing is a form of thinking, which is also a tool to make the other person or the reader think. By writing, students are able to construct a variety of science or knowledge possessed in a post, either in the form of essays, articles, scientific reports, news, short stories, poetry and so on. The purpose of teaching writing in school is that the students have the ability to write so that students do not think that the writing skills is a complex activity. In addition, the overall objective of learning to write in school is that the students are able to understand and be able to express what they catch, ideas, opinions, messages and feelings in written form. 
Writing is an activity that is difficult for most people, both in the mother tongue and a foreign language. Lack of vocabulary, lack of understanding of the grammar, and their confusion about the structure of text are several reasons that make students afraid to write. Students often assume writing as an activity that bored, not profitable, and probably because writing is often done as homework, which doesn't have much fun (Hadfield Charles and Hadfield, 2005). Most of teachers are more interested in teaching students in traditional ways. Usually, teachers only give a few theories about how to make a good article without the practice of writing to students. Furthermore, students only know about theories in making good writing, but students do not know how to express ideas and thoughts in writing

Such as that found of researcher from the observation in class SMP Nasrani 1 Medan on July 29, 2019 when the English class, found the problem in learning activities. That is still low of student motivation when learning activities particularly in writng, this condition is evidenced by the number of students who perform other activities such as talking, joking, even sleepy when the activity of the learning takes place because in the learning activities, teachers are still using methods that are tedious, namely expository and methods of lectures and assignments, so that learning activity was dominated by the teacherthough each subject matter certainly requires the implementation of a varied strategy because the learning objectives are also different.

Of these problems, it is necessary if it were carried out research on the implementation of a new learning strategies by teachers. The title of the research to be conducted by the researchers that "The Implementation Of Pen Pal Project To Teach Writing Skill Of Recount Text At The Second Grade Of SMP Nasrani 1 Medan"

"Pen Pal 'is a term that describes an activity of exchanging letters to others to be friends with someone. Pen-Pal done through writing a letter on a piece of paper and that will be sent to each of their pen pals through the pen pal sites on the internet. This could be a unique activity for students because students are familiar with the use of email in their gadgets in this era. In this letter, students share information about themselves and their experiences. The use of pen pals may motivate the willingness of students in writing in a humorous way. This strategy has been widely used in a variety of formal educational settings and has been used with participants from all age groups and levels of language proficiency (Larotta and Serrano, 2012). Writing letters to pen pals allow students to share their passion with their pen pals. A study has been conducted by Vera Mello (1998) provide evidence that the pen pal project is an effective way to help students to improve their writing skills. The findings indicate that this project gives the students improve the skills of reading, writing and cognitive, namely the skills to interact with others. The project also gives them the opportunity to communicate effectively in the English language to express their ideas and thoughts on a particular topic they like.

Pen pal project spark a sincere interest in learning. According to Garcia (2013), the implementation of a pen pal 
program has been shown to increase student's knowledge of desire to have multicultural experiences. Shandomo (2009) identifies the objectives of pen palprograms to include writing and reading for genuine purpose for audiences to celebrate differences and similarities. Recent research suggests pen pal practices support, nurture and motivate early adolescence reading habits (Gambrell, 2015). Students enjoy getting to know each other while experiencing an increase in cultural knowledge without forced effort from educators (Garcia, 2013).Although, pen pal relationships are generally short lived, it is an experience never forgotten and often reflected on through adulthood.

Recount text is a type of English text that is studied by eighth graders at school. Retelling of one's own experiences is an activity in which we tell people about something that has happened in our lives. Maybe about what we did on vacation or about interesting things that happened in the past. Anderson and Anderson define the recount text as a piece of text that recounts past events, usually in the order in which they occur. From this definition, it can be seen that the recount text consists of chronological events of the past. It further means that we cannot write events randomly because there is a general structure to follow that will make the text easier to understand. This type of text is not only used at school but also at other media written and electronic, it's used in many real social contexts. For example is used in diary, blog, letter, biography, travel report, police report, sport report etc.
A recount text usually has three main sections: Orientation, Sequence of Events and Reorientation.

a. Step 1: Orientation

Orientation introduces the participants, place and time. It provides all the necessary background information to make sense of the text. $5 \mathrm{~W}$ questions (Who, What, Where, When and Why) are used in order to have systematic and thorough information. Therefore, what happened, who or what was involved in the story, why, where and when the events occurred needed to write.

b. Step 2: Sequence of Events

This step tells the sequence events that happened in the past based on the time and place when it occurred.

c. Step 3: Reorientation

It consists of optional closure of events or it can be stating personal comment of the writer to the story.

\section{B. METHOD}

\section{Design}

This study is design descriptive using a qualitative approach to the data generated is in the form of words and sentences.

\section{Subject or Participant ( take one term)}

Subjects in this study consist of teachers and students of class VIII SMP Nasrani 1 Medan in academic year 2019/2010. Research subject was selected, English teachers using purposive sampling technique meanwhile, for the students using snowball sampling technique.

\section{Instruments}


The instruments used in this research were questionnaire and interview. The questionnaire consisted of 10 items, including four factors affecting of implementation pen pal project. The questionnaires was formed as Likert scale like format (strongly agree, agree, disagree, strongly disagree). The interview was used to support the data, and to trace reasons of implementation of pen palproject consisting of open questions that required teacher to mention her reasoning.

\section{Data Collecting Technique}

The qualitative data collection inquirer deals with data that are in the form of words or pictures rather than numbers and statistics ( Ary et all, 2010:424). Data that are in form of information are gotten by researcher from teacher by interview transcript and questionaire from the students.

\section{Data Analysis Technique}

To present the data so that it is easy to understand, the data analysis steps used in this study are Analysis Interactive Model from Miles and Huberman, which divides the steps in data analysis activities with several parts, namely data collection, data reduction, data display, and drawing conclusions or verification.

1. Data Collection

In the analysis of the first model, data collection from interviews, observations and various documents in accordance with the categorization in accordance with the research problem is then developed to sharpen the data through further data search.

2. Data Reduction
Data reduction is a form of analysis that sharpens, classifies, directs, disposes of unnecessary data and organizes data in a way that is easily done so that it can be made final and accessible (Miles and Huberman, 2007: 16).

3. Data Display

Data Display is a series of information organizations that allows the conclusions of research to be carried out. Display of data is intended to find meaningful patterns and provide the possibility of drawing conclusions and providing action (Miles and Huberman, 2007: 84).

4. Drawing Conclusion

Drawing conclusion is part of a complete configuration activity (Miles and Huberman, 2007: 18). The conclusions were also verified during the study. Conclusions are drawn since the researcher compiles records, patterns, statements, configurations, directions of cause and effect, and various propositions (Harsono, 2008: 169).

\section{RESULT AND DISCUSSION Result}

This research was conducted in four meetings. first of all, the researchers introduced a pen pal project learning strategies to the teacher of English and then explains the stages of implementation so that teachers are already familiar with the purpose and objective researchers so that they can teach it to the students properly. At the first meeting of researchers conducted observations of writing materials to students, it aims to make students better understand the benefits and how to write well so that students are motivated in writing activities. 
When the students were familiar with it, at the second meeting of students then taught with texts recount matter of understanding, generic structure to recount instances of the text. From the observations of researchers, it seems the students already understand this kind of text so that the teacher can easily explain it to the students. but found some problems when the student is given training teachers to write a recount text, many students write recount text does not fit based on their general structure, then there also write to the tenses that are not right and there are some students who have difficulty in vocabulary that teacher must explain in detail about the general structure of recount text, to better understand the teacher gives an unorganized text based on their general structure and asks the students to fix it. finally the students are able to write correctly and for students who have difficulty in vocabulary, The teacher suggests students to use the dictionary and invites students to ask the teacher until students understand the recount text.

At the third meeting, pen-pal project was introduced by teacher to the students and then explain what students have to do in this pen pal project. First of all the students were introduced to the E-mail which is basic so that students can make an account to sign into the site pen pals on the Internet, according to the observations of researchers students are familiar with the use of E- mail in this day so that students can easily account sign up the pen pal sites on the internet. Next the students are asked to look for their pen pal in the pen pal sites by using search filters that are directed by the teacher, it aims to enable students to get their pen pals in accordance with the expected criteria. Once they get a pen pal, respectively, students then directed to write a recount text to their pen pals based on a topic given by the teacher. First of all the students write their letters in the form of a draft which is then corrected by their peers, in addition to the permanent teachers accompanying them in writing to help students if it finds it difficult when writing. From observations of student researchers are excited to write letters to their pen pals based on a topic given by the teacher, they began to think of new ideas and stringing words are interesting to them and writing to their pen pals. After that, they were writing given to teachers to be revised. First of all the students write their letters in the form of a draft which is then corrected by their peers, in addition to the permanent teacher accompanying them in writing to help students if it finds it difficult when writing. From observations of student researchers are excited to write letters to their pen pals based on a topic given by the teacher, they began to think of new ideas and stringing words are interesting to them and writing to their pen pals. After that, they were writing given to teachers to be revised.

At the fourth meeting teacher give the revision of the letter to be repaired by the students and then sent to their respective pen pals. then, the teacher asks students to respond to a reply letter from their pen pals so that pupils more active in writing especially those in writing recount text. From the questionnaire results showed that the students are very interested and excited to implementation of pen pal 
project, a learning strategy is good in motivating them to write and again a topic given by the teacher are highly relevant to their experience everyday so they can easily tell about themselves in the mail recount text to their pen pals and agree learning strategies continues to be done in improving writing skills.

\section{Discussion}

When the teacher taught pen pal project of recount text, researchers found that students had brought some difficulty in deciding what they want to write. So that teacher help provide some of the topics for students related to their daily lives. As for some of the topics given by the teacher are: Holyday, a pleasant experience, a frightening experience, camping, birthday parties, meet fans, that embarrassing experience. The most favorite topics were chosen by the students was a pleasant experience. More than half of the students in the class chose a pleasant experience as a topic in their letter. then, students also have difficulty in the translation of the word that they made so that teacher ask other students to help their friends and use a dictionary. When the students' problems can not be overcome, then the teacher help the student. However, in the learning process of teachers still have to perform, demonstrate, motivate and provoke, support, respond and evaluate it before, during and after the students wrote (Hamer, 2004). From the observations the researchers can say that teachers do a good learning process. Teachers lead students in solving problems they encounter, designing a project plan in the first meeting, the second meeting teacher monitored progress of the students and the project. in the third meeting, the teacher evaluated the students' letter has written and the fourth meeting asked the students to send letters to their pen pals. Most of the students are very excited and interested in the implementation of this pen pal project and greatly assist them in learning English, especially in writing. Thus, they agreed that the application of pen pals need to continue the learning process.

There are many sites on the internet pen pals but researchers only use one pen pal site that https://interpals.net/ in this research.

\section{CONCLUSION AND SUGGESTION}

\section{Conclusion}

From the analysis can be concluded that the project could be used as a pen pal new teaching strategies for teachers to improve students' skills in writing especially those writing texts recount. pen pal project implementation can spur the spirit of students to write and assisted with relevant topics by the teacher. From this project the students also find a new experience which they can communicate with others outside the country telling each other and get to know one another and in this project the students also began to grow in terms of the vocabulary of the English language. So that the students are interested to continue to communicate with their pen pals although its research period has been completed.

\section{Suggestion}

To improve the process of learning to write effective, teachers must actively look for interesting strategies and materials to teach. In teaching recount text, teachers must also provide appropriate topics with students' writing ability to accommodate the 
student's knowledge of having to adjust in their textbooks. In addition, teachers should provide a wide range of topics relating to student life, values, social norms and culture so that they can write well. It is also important that teachers always encourage students in such a way that motivates them, such as the encouragement or praise. Researchers also advised teachers to continue learning strategies for the pen pal program per semester or a year so,

Finally, the researchers realized that this research is still far from perfect. So, the researchers hope there will be other researchers who will conduct similar research but in a different perspective.

\section{ACKNOWLEDGEMENT}

Give thanks to the almighty God for the wonderful chances and blessing that enable the researcher accomplished this scientific article which entitled: "The Implementation Of Pen-Pal Project To Teach Writing Skill Of Recount Text At The Eight Class Of SMP Nasrani 1 Medan"

The authors has traveled a long journey in the context of completing the writing of this scientific article. Many obstacles were encountered in its compilation, but thanks to God so that the author successfully completed the preparation of this scientific article. Therefore, with full humility, on this occasion, the author should thanks to:

1. Dr. Chrismis Novalinda Ginting, SSit, MKes, as Chancellor of Universitas Prima Indonesia.

2. Natalia Widya Pasca Tarigan, S.Pd., M.Hum, as Head of Study
Program of Universitas Prima Indonesia.

3. Irma Khoirot Daulay, S.S., M.Hum., as Academic Advisor who has giving ideas and guided the researcher to finish this research with her patiently.

4. The researcher beloved parents, who always help and support researcher to accomplish the script.

5. Sofian Indris Simanulang, S.Pd, as Headmaster of SMP Nasrani 1 Medan who has allowed the researcher to get the data from his school.

6. Leo Sartika Pasaribu, M.Pd, as English Teacher at SMP Nasrani 1 Medan who has allowed the researcher to analyzed his class.

7. Fellow field practice, students of HKBP Nomensen University who helped support the completion of this research

8. All of my friends that the researcher can not mention one by one who have support the researcher to finish this research.

The researchers hopes that this research will give contributions to the improvement of the English teaching and learning process. However, the writer also realizes that this writing is still far from being perfect. Therefore, all criticisms and suggestions will be appreciated.

\section{BIO-PROFILE}

Daniel, Eka, Ana, and Isni are students at Prima Indonesia University of Medan, This study is one of the research interests that they both work together to get a bachelor's degree in education. Irma khoirot is a 
English lecturer in Prima Indonesia University and as a supervisor in this research.

\section{REFERENCES}

Ary, et al. 2010. 2006. Introduction to

Research in Education. Wadsworth:

Cengage Learning

Astrid. (2010). Improving Writing Recount Text Trough Personal Journal Unpublished: Tadulako University Palu.

Gambrell, L. B. (2015). Getting Students Hooked on the Reading Habit. The Reading Teacher, 69(3), 259-263.

Garcia, B. N. (2013) Pen pal program's efficacy on teaching students about multiculturalism and diversity. St. Mary's College of California. pps 86,1544915. Available at: http://gradworks.umi.com/15/44/154491 $\underline{5 . h t m l}$

Hadfield, Charles and Hadfield, Jill. 2005. Writing Games: A collection of Writing Games and Creative Activities for Low Intermediate to Advanced Students of English. New York: Longman.

Harmer, Jeremy. 2004. How to Teach Writing. England: Pearson Education Ltd.

Harsono, 2008. Pengelolaan Perguruan Tinggi.Yogyakarta: Pustaka Pelajar.

Imron Rosidi, (2009). Menulis Siapa Takut. Yogyakarta: Kanisius.
Larrotta, Clarena and Serrano, Arlene F. 2012. Pen Pal Writing: "A Holistic and Socio-Cultural Approach to Adult English Literacy". Texas: Journal of Adult Education.

Mark Anderson and Kathy Anderson (1997) Text Types in English 1, Australia: Macmillan Education Australia PTY LTD.

Sugiyono. 2010. Metode Penelitian Kuantitatif dan Kualitatis $R \& D$. Bandung: Alfabeta

Mello, Vera. 1998. Report on a Penpal Project, and Tips for Penpal-Project Success. ITSLJ Vol IV, No.1.

Miles, Mattew B dan Amichael Huberman. 2007. Analisis Data Kualitatif Buku Sumber tentang Metode-Metode Baru. Terjemahan Tjetjep Rohendi Rohisi. Jakarta: Universitas Indonesia.

Shandomo, H.M. (2009). Getting to know you: cross-cultural pen pals expand children's world view. Childhood Education, 85(3).

The English Syllabus of Eight Grade of Junior High School from the 2013 Curriculum. 